\title{
Primitive Vascular Plants and Microfossils from the Río Seco de los Castaños Formation, San Rafael Block, Mendoza Province, Argentina
}

\author{
Eduardo M. Morel, Carlos A. Cingolani, Daniel Ganuza, \\ Norberto Javier Uriz and Josefina Bodnar
}

\begin{abstract}
In this contribution we describe fossil plant remains from Río Seco de los Castaños Formation, at San Rafael Block, Mendoza Province, Argentina. The fossil plants comprise non-forked and forked axes without or with delicate lateral expansions, which are assigned to Bowerophylloides $c f$. mendozaensis and Hostinella sp. We refer them to primitive land plants and discuss about their systematic affiliation. Furthermore, we mention the presence of a diverse acritarch assemblage present in the same lithostratigraphic unit. On the basis of the taxonomical information and stratigraphic correlation, we could infer that Río Seco de
\end{abstract}

\footnotetext{
E.M. Morel $(\bowtie) \cdot$ D. Ganuza · J. Bodnar

División Paleobotánica, Museo de La Plata, UNLP, Paseo del Bosque s/n,

B1900FWA La Plata, Argentina

e-mail: emorel@fcnym.unlp.edu.ar

D. Ganuza

e-mail: dganuza@fcnym.unlp.edu.ar

J. Bodnar

e-mail: jbodnar@fcnym.unlp.edu.ar

E.M. Morel

Comisión de Investigaciones Científicas de la Provincia de Buenos Aires (CIC),

La Plata, Argentina

C.A. Cingolani

Universidad Nacional de La Plata and Centro de Investigaciones Geológicas,

Diag. 113 n. 275, CP1904 La Plata, Argentina

e-mail: carloscingolani@yahoo.com

C.A. Cingolani · N.J. Uriz

División Geología, Museo de La Plata, UNLP, Paseo del Bosque s/n,

B1900FWA La Plata, Argentina

e-mail: norjuz@gmail.com

C.A. Cingolani · J. Bodnar

Consejo Nacional de Investigaciones Científicas y Técnicas (CONICET),

La Plata, Argentina

C.A. Cingolani (ed.), Pre-Carboniferous Evolution of the San Rafael Block, 
los Castaños Formation has an Early Devonian age. The taphonomical conditions of this fossil association would indicate that the plants were transported some distance from their presumed coastal and riverbank habitats. Finally, studying the amount and the percentage of kaolinite within charcoal levels, warm to cool temperate paleoclimatic conditions were deduced.

Keywords Vascular plants - Microfossils - Lower Devonian - San Rafael block • Mendoza

\section{Introduction}

The main focus of this chapter is the study of the first record of primitive vascular plants from Río Seco de los Castaños Formation (RSC) that is one of the "pre-Carboniferous" units of the San Rafael block (González Díaz 1972, 1981). Based on the stratigraphical and paleontological evidence, the age of this formation is considered between the Late Silurian and Early Devonian. The fossil remains described here were found at Atuel River Creek, where the type section of RSC is located about $12 \mathrm{~km} \mathrm{NE}$ of El Nihuil town (Fig. 1).

At this outcrop the unit comprises near $600 \mathrm{~m}$ of marine siliciclastic sedimentary rocks, mainly green sandstones and grey mudstones (Fig. 2). The fossiliferous stratum with fossil plants is placed $60 \mathrm{~cm}$ above a charcoal bed. This charcoal is interbedded with a massive sandstone body, and it is composed of a mixture of silty-quartz, illite-kaolinite clays and amorphous organic matter (Morel et al. 2006; Manassero et al. 2009). In order to study the origin of the charcoal, three kinds of analyses were done: Total Organic Carbon (in ACME Lab, Canada), isotopic deviation of ${ }^{13} \mathrm{C}\left(=\delta{ }^{13} \mathrm{C}\right)$ in Activation Laboratories LTD, Ontario, Canada and pyrolysis quantification (in GeoLab Sur S.A., Buenos Aires, Argentina).

The sedimentary rocks which contain the fossil plants were interpreted as deposits of suspension and fall out from low density turbidity currents in a distal platform (Manassero et al. 2009). The paleoenvironmental conditions are shallow marine water near the coastline as can be inferred from the taphonomical attributes of the fossil plants. A similar siliciclastic environment has been recognized in the Upper Silurian-Lower Devonian Villavicencio Formation of southern Precordillera (Edwards et al. 2001). However, the RSC unit has two distinctive sedimentological characteristics: conglomerate channels and organic-matter-rich beds.

The plant debris comprises non-forked and forked axes without or with delicate lateral expansions. Sporangia were not preserved in any sample. Although these plants were previously assigned to lycophytes (Morel et al. 2006, 2007), here we discuss their possible filiations and systematic relationships. 


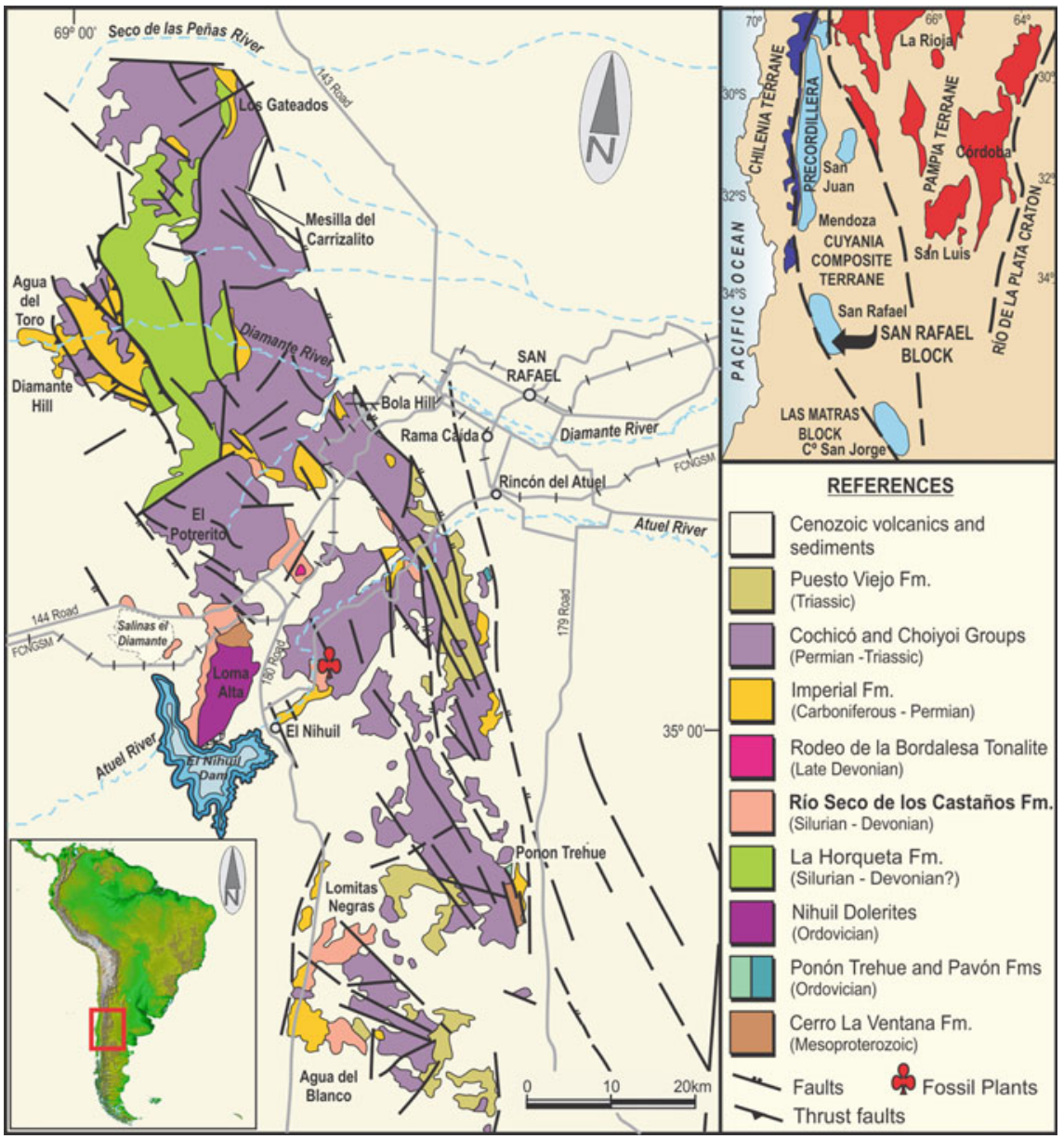

Fig. 1 Geological sketch map of the San Rafael BlockSan Rafael Block, showing the outcrops of the Río Seco de los Castaños Fm. The red symbol indicates the fossil plants locality

\section{Paleontological Background}

The paleontological contributions about RSC are scarce. The first reference corresponds to the coral Pleurodyctium sp. by Di Persia (1972) found in Agua del Blanco region, but lacks an original description. Pöthe de Baldis (1999) in an unpublished report has mentioned a palynological association, in the type section of the RSC unit at Atuel creek, and in the same sequence where the plant debris was found. Those palynomorphs have a very high-grade of thermal alteration $(<4$ of Staplin scale) making the generic assignment relatively difficult. Acritarchs, algae prasinophytes, and probably plant spores were recognized, which are listed below and reproduced in Fig. 3. 
Fig. 2 Stratigraphic column of the San Rafael Block

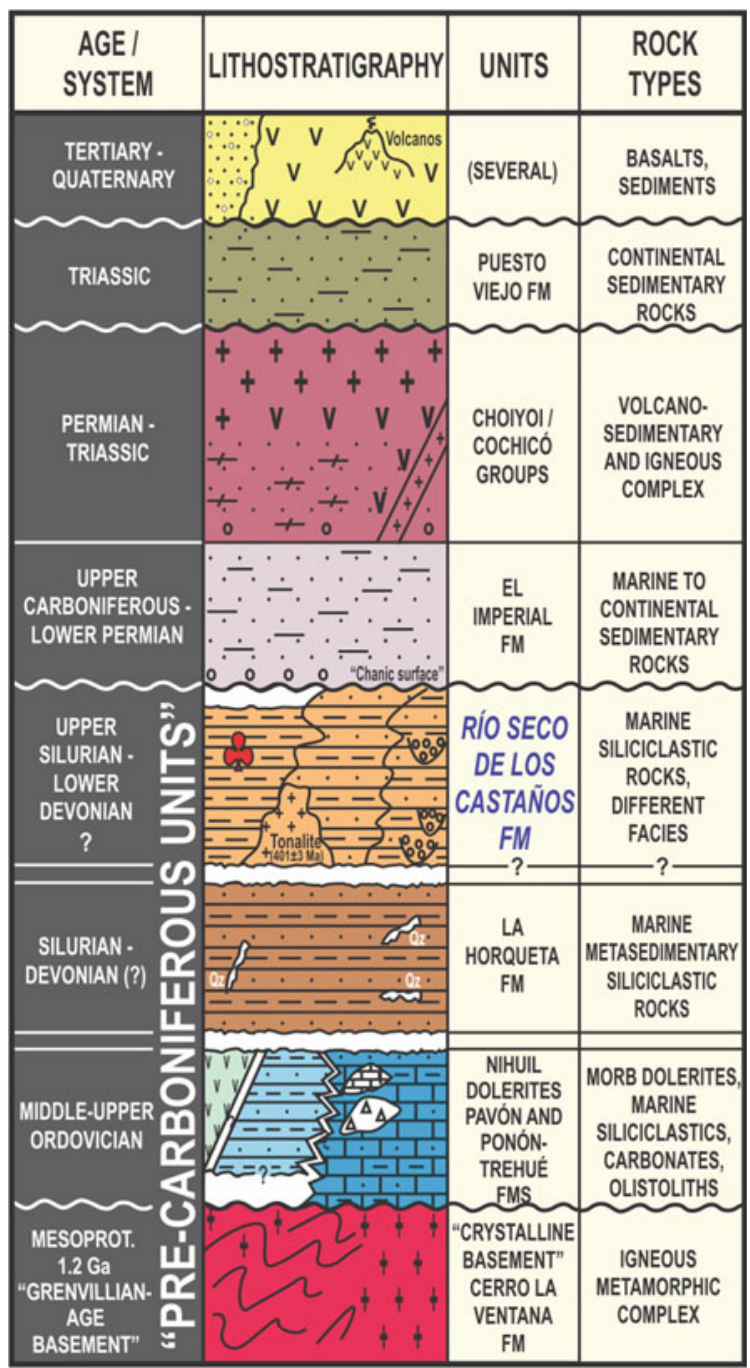

Acritarcha: Ammonidium alloiteaui (Deunff) Deunff, Ammonidium cf. Ammonidium hydraferum (Stockmans and Williére) Pöthe de Baldis, Lophosphaeridium sp., Micrhystridium sp. aff. Micrhystridium stellatum Deflandre, Protoleiosphaeridium sp., Veryhachium trispinosum (Eisenack) Stockmans and Williére.

Prasynophyceae: Veliferites sp. cf. Veliferites jachalensis Pöthe de Baldis, Cymatiosphera sp.

Plant spores: Streelispora?

Although the palynomorph elements are not diverse, the presence of acritarchs would indicate a shallow marine paleoenvironment, near the coast as it is suggested 
(a)

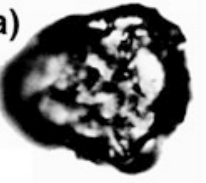

(e)

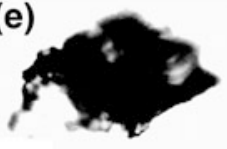

(i)

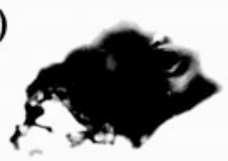

(m)

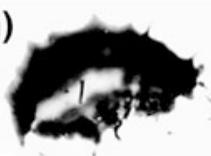

(q)

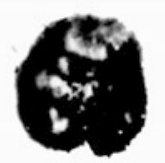

(u)

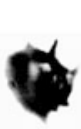

(b)

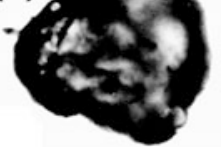

(f)

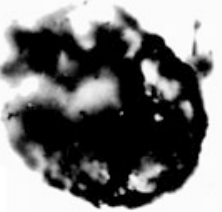

(j)

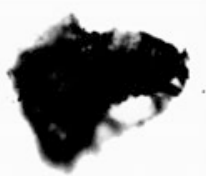

(n)

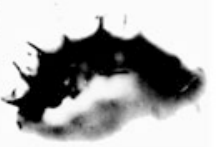

(r)

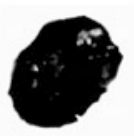

(c)

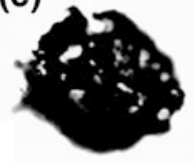

(g)

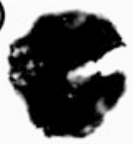

(k)

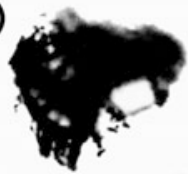

(o)

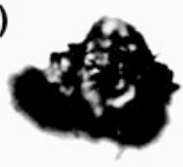

(s)

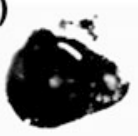

(d)

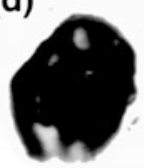

(h)

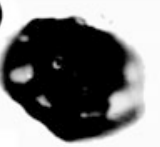

(I)

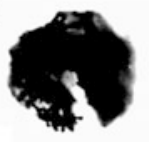

(p)

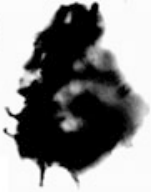

(t)

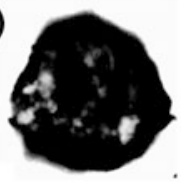

Fig. 3 Microfossil assemblage after Pöthe de Baldis (1999). a and b Streelispora sp.; c, d and h Spores?; e and i Veliferites jachalensis; f Cymatiosphaera sp.; $\mathbf{g}$ and $\mathbf{l}$ Spores?; j and $\mathbf{k}$ Duvernaysphaera? sp.; $\mathbf{m}$ and $\mathbf{n}$ Ammonidium sp. cf. Ammonidium hydraferum; $\mathbf{o}$ and p Ammonidium sp. cf Ammonidium alloiteaui; $\mathbf{q}$ Lophosphaeridium sp.; $\mathbf{r}$ and $\mathbf{s}$ Protoleiosphaeridium sp., t Micrystridium sp.; $\mathbf{u}$ and $\mathbf{v}$ Micrystridium sp. cf. Micrystridium stellatum; $\mathbf{w}$ and $\mathbf{x}$ Veryhachium trispinosum

by the presence of some spores. The presence of Veliferites sp. cf. Veliferites jachalensis Pöthe de Baldis, would imply a Late Silurian age for this association, since this taxon is known from the Silurian (Ludlow) of the Argentine Precordillera (Los Espejos Formation). 
It is important to mention that the palynoflora studied by Rubinstein (1997) from outcrops located near the 144 road at $\mathrm{km} 702$ and assigned to 'La Horqueta Formation' by this author, were afterwards considered as part of the RSC sensu González Díaz (1981) based on sedimentary rock attributes and the presence of the ichnofacies of Nereites-Mermia (Cuerda and Cingolani 1998, Poiré et al. 2002 and discussion in Manassero et al. 2009). Rubinstein (1997) described the following Upper Silurian palynoflora:

Ammonidium ludloviense (Lister) Dorning (1981)

Dactylofusa cabotti (Cramer) Fensome et al. (1990)

Dactylofusa striatifera (Cramer) Fensome et al. (1990)

Evittia denticulata denticulata (Cramer) Le Hérissé (1989)

Fimbriaglomerella divisa Loeblich Jr. and Drugg (1968)

Leiofusa estrecha Cramer (1964)

Tylotopalla sp. cf $T$. pyramidalis (Lister) Dorning (1981)

Baltisphaeridium spp.

Leiofusa sp.

Leiosphaeridia spp.

Retisphaeridium sp.

Veryhachium? sp.

This association shares some genera with the assemblage mentioned by Pöthe de Baldis (1999), such as Ammonidium and Veryhachium.

Poiré et al. (2002) have recognized different ichnogenera in the Agua del Blanco region, as follows, Arenicolites, Bergaueria, Cochlichnus, Cruziana, Gordia, Mammlichnus, Palaeophycus, Phycodes, Rusophycus and Teichichnus. This ichnofacies represents a well oxygenated environment and it is interpreted as a proximal to shallow marine platform, with dominance of subtidal environment. The trace fossils are developed in soft substrates of moderate energy (Manassero et al. 2009). On the other hand, Pazos et al. (2013) documented the ichnogenera on the 144 road (km 702) locality that contains dominantly Nereites irregularis Schafhäutl, Helminthopsis and less abundant arthropod trackways and grazing traces. Microbial mats are very abundant but clearly not related to Nereites. At the Atuel creek locality Nereites is also the most abundant ichnofossil but it contains more than one ichnospecies: Nereites irregularis and one beautifully preserved specimen of Nereites cambrensis Murchinson, the type ichnospecies of the ichnogenus. Other specimens are assignable to the questionable Nereites delpeyi Borrouilh, a dubious valid ichnospecies that probably is a junior synonym of Nereites missouriensis Weller. Other well preserved trace fossil is Dictyodora in upper relief expressions. This ichnogenus (Poiré et al. 1998; Pazos et al. 2013, 2015) contains several ichnospecies, with an apparently ichnostratigraphic value. At the Atuel creek RSC outcrop the ichnogenera Dictyodora Weiss is recorded. The ichnospecies recognised include Dictyodora scotica and Dictyodora tenuis, and a new ichnospecies, Dictyodora atuelica. The succession studied by Pazos et al. (2015) contains abundant microbial mats (wrinkle marks), either as extended surfaces or patches. 


\section{Paleobotany}

\section{Division Tracheophyta}

Incertae Sedis

Genus Bowerophylloides Edwards et al. (2001)

Bowerophylloides cf. mendozaensis Edwards et al. (2001) (Fig. 4a-f)

Description Impression of delicate herbaceous stem fragments, with dichotomizing sterile axes covered by crowded narrow enations, in spiral arrangement. The bases of enations are fusiform when axes are defoliated. The fossil plants present stems with enations and unbranched axes with irregularly shaped patches. Description is based on 7 fragments, all of which bear enations showing varying degree of fragmentation. No anatomical details have been preserved. Branching is
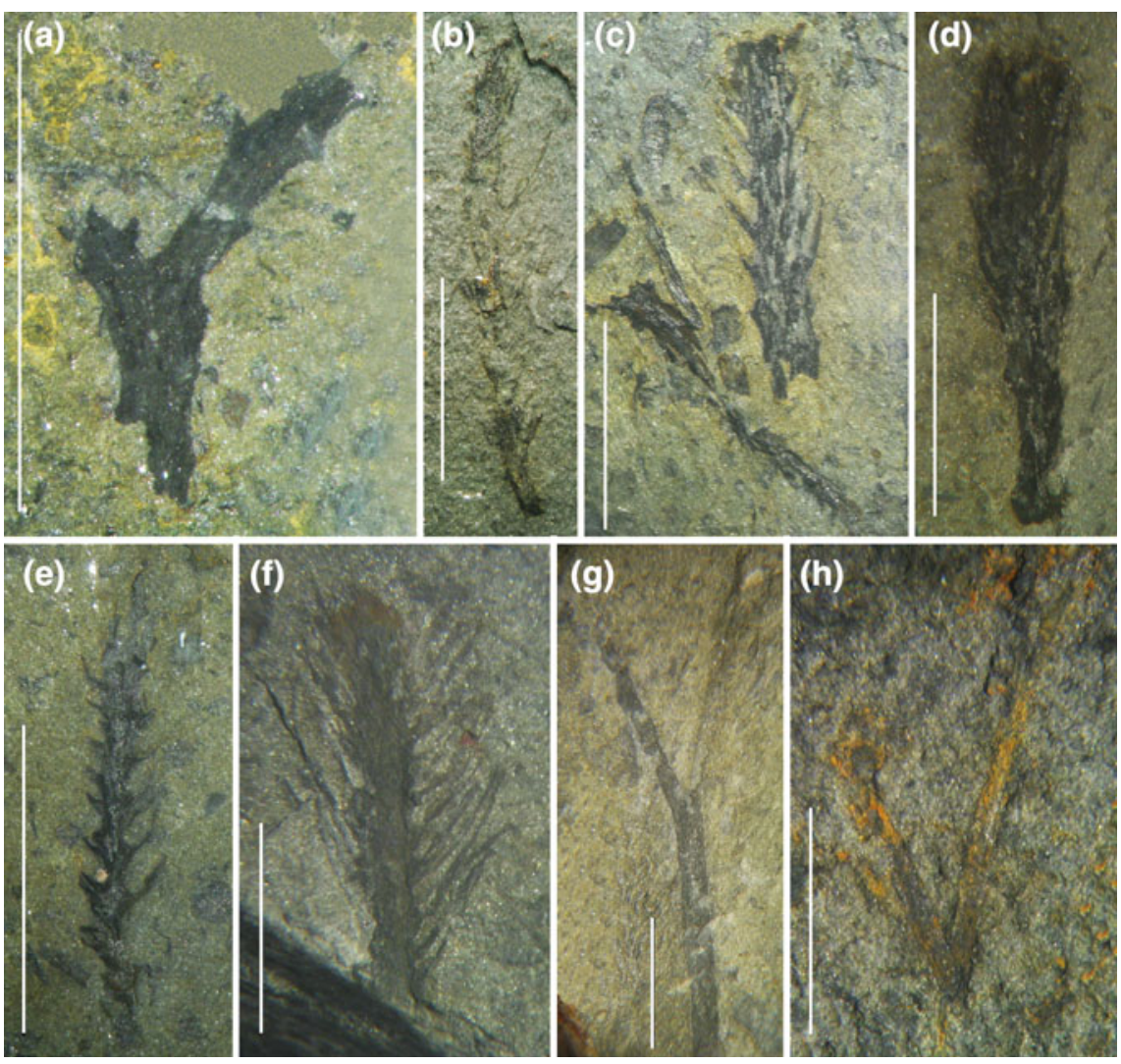

Fig. 4 a-f Bowerophylloides cf. mendozaensis Edwards et al. (2001). a LPPB 13814b. b LPPB 13816b. c LPPB 13817a. d LPPB 13829a. e LPPB 13818a. f LPPB 13830. g-h Hostinella sp. g LPPB 13831. h LPPB 13832. Scale bar $0.5 \mathrm{~cm}$ 
isotomic-dichotomous (in one specimen: LPPB 13814). The largest specimen reaches $10.7 \mathrm{~mm}$. Stem width (excluding enations) ranges from 0.5 to $1.3 \mathrm{~mm}$. Enations in profile attached to the sides of the stem show swollen decurrent bases extending into linear structures that are straight or distally slightly curved. They are inserted at $45-50^{\circ}$ angles to the stem. The regular spacing between these enations suggests a regular phyllotaxis, which can be defined as spiral. The bases of enations are subcircular to fusiform in outline, have a central prominence, and range from 0.1 to $0.3 \mathrm{~mm}$ wide and 0.2 to $0.3 \mathrm{~mm}$ long. The shape of the free distal part of the enations, are probably linear to slightly spatulate (LPPB 13816). Enations show no evidence for a central trace.

Comparisons This material is assigned to Bowerophylloides mendozaensis Edwards et al. (2001), because of morphological similarities to material from Villavicencio Formation (Mendoza province; $c f$. Edwards et al. 2001). The specimens described above have sterile axes covered by narrow, elongate projections (enations), directed towards the apex, truncated in the apex, with a maximum length of $0.31 \mathrm{~cm}$ and a maximum width of $0.03 \mathrm{~cm}$ near the base. Every dimension of these samples agrees with the original material described by Edwards et al. (2001) (Table 1).

This type material of Bowerophylloides mendozaensis Edwards et al. (2001) had been originally assigned to Baragwanathia (Cuerda et al. 1987). Such identification was rejected because (1) there is little direct morphological similarity with Australian Baragwanathia with its elongate flexuous leaves (e.g. Lang and Cookson 1935), and (2) there is no anatomical evidence of microphylls.

In RSC samples, it is also impossible to confirm the vascular status of the enations, viz. whether or not they are microphylls, with obvious consequences for unequivocal identification of these fossils as the leafy shoots of lycophytes

Table 1 Comparative table of the RSC plant specimens and type material of Bowerophylloides

\begin{tabular}{l|l|l|l|l|l|l|l|l|l}
\hline LPPB & $13816 \mathrm{a}$ & $13818 \mathrm{a}$ & $13817 \mathrm{a}$ & $13814 \mathrm{~b}$ & $13822 \mathrm{a}$ & 13819 & 13829 & 13830 & $\begin{array}{l}\text { Bowerophylloides } \\
\text { (Edwards et al. 2001) }\end{array}$ \\
\hline $\begin{array}{l}\text { Axis length } \\
\text { above }\end{array}$ & 9.3 & 7.5 & 6.9 & 5.3 & 7.1 & 5.0 & 10.7 & 9.95 & $\begin{array}{l}(3=n) \times 2.6+2.7 \\
\text { below and above }\end{array}$ \\
\hline Axis width & 0.5 & 0.5 & 1.0 & 0.9 & 0.6 & 0.35 & 1.26 & 0.8 & $\begin{array}{l}1.35-1.9 \\
(4=n) \times 0.6 \text { above } \\
\text { dichotomy }\end{array}$ \\
\hline $\begin{array}{l}\text { Enation } \\
\text { length }\end{array}$ & 3.1 & 1.0 & 0.9 & - & 0.9 & 1.5 & 2.63 & $\begin{array}{l}4.6- \\
4.4\end{array}$ & $\begin{array}{l}<2.0 \text { But probably } \\
\text { greater }\end{array}$ \\
\hline $\begin{array}{l}\text { E. basal } \\
\text { width }\end{array}$ & 0.3 & 0.1 & 0.16 & - & 0.5 & 0.3 & & $0.19-0.32$ \\
\hline $\begin{array}{l}\text { E. basal } \\
\text { length }\end{array}$ & - & - & 0.2 & 0.3 & & & 0.57 & $\begin{array}{l}0.42- \\
0.55\end{array}$ & $0.27-1.8$ \\
\hline $\begin{array}{l}\text { "Lamina" } \\
\text { width }\end{array}$ & $45-50^{\circ}$ & $40-45$ & $45-50^{\circ}$ & & $50^{\circ}$ & $\begin{array}{l}45- \\
50^{\circ}\end{array}$ & $\begin{array}{l}40- \\
47^{\circ}\end{array}$ & $\begin{array}{l}40- \\
45^{\circ}\end{array}$ & $\begin{array}{l}20-35^{\circ} \text { distally- } \\
\text { c50 proximaly }\end{array}$ \\
\hline $\begin{array}{l}\text { Insertion } \\
\text { angle }\end{array}$
\end{tabular}


Therefore, the assignation to Bowerophylloides, a genus belonging to primitive incertae sedis vascular plants, is supported by the following features: (1) Bowerophylloides has longer and wider axes but dimensions of the enations are comparable, i.e. they fall within the range of the Bowerophylloides material, (2) in neither of them is possible to determine a phyllotaxy, but regularity of spacing of emergences in profile, together with the shape of enation bases in face view, suggests a spiral phyllotaxy, (3) angles of insertion of RSC material match with those of the Bowerophylloides type specimen, and (4) the material certainly fits the generic diagnosis of Bowerophylloides, although spatulate leaves would be needed to allow precise specific identification.

Genus Hostinella Barrande ex Stur 1882

Hostinella sp. (Figure 4g, h)

Description Fragments of axes with dichotomous isotomous branching, usually with little change in diameter of the daughter branches. The axes are branched only once. Some specimens show evidence of central strand (LPPB 13832). The fragments reach $28.1 \mathrm{~mm}$ of length, and a width of $0.6-1 \mathrm{~mm}$ before dichotomy and $0.6-0.8 \mathrm{~mm}$ above dichotomy.

Studied material: LPPB 13831, 13832.

Comparisons Isotomously branching axes are traditionally referred to genus Hostinella. This taxon had been used for a variety of naked axes with dichotomous or pseudomonopodial branching with occasionally, bud-like protuberances in the upper angle of the dichotomy (Gensel and Andrews 1984). This genus has not great significance as biological entities, thus the RSC samples cannot be assigned to any group of vascular plants.

\section{Discussion}

\section{Taphonomical considerations}

The plant assemblage presents a low diversity and high fragmentation of the specimens. This can be explained by taphonomical conditions, since the plant debris were preserved in heterolithic siltstone/sandstone strata, inferred as fair weathered deposits in a subtidal coastal environment on a shallow shelf. The plants would have been transported some distance from their presumed coastal and riverbank habitats, for which we have no direct information (Poiré and Morel 1996; Edwards et al. 2009). 


\section{Systematic considerations}

Despite that Bowerophylloides mendozaensis was considered as an enigmatic "leafy" shoot taxon (Edwards et al. 2001), some characters present in the genus confirm that it belongs to a primitive vascular plant. Particularly the enations show evidence of a regular phyllotaxy which can be defined as spiral, and they have a swollen basis that remains attached to the axis. These characteristics could link this taxon to the lycophyte lineage ( $c f$. Kenrick and Crane 1997).

\section{Correlations}

The low diversity and high fragmentation of this plant assemblage makes difficult the correlation with other coeval paleofloras. The occurrence of Bowerophylloides, present in Lower Devonian Villavicencio Formation, would suggest a similar age for RSC fossil assemblage. The microflora of Villacencio Formation (Rubinstein 1993) shows abundant spores and only three species of acritarchs, Veryachium cf. downiei Stockmans and Willière, Veryachium cf. lairdi Deunff, and Micrhystridium sp. These genera are also present in RSC Formation (see Paleontological background). Even though the biochrons of these acritarch taxa are extended, their presence is another element for correlation.

\section{Charcoal level}

The Total Organic Carbon analysis gave a value of $1.08 \%$, which represent an important proportion. The isotopic deviation of ${ }^{13} \mathrm{C}\left(=\delta{ }^{13} \mathrm{C}\right)$ analysis showed a value of $-26.3 \%$. Such a deviation is an average amount of the land vegetation, since the land plants are classified in two main groups: $\mathrm{C} 3$ and $\mathrm{C} 4$, according to their metabolic photosynthetic mechanism. The $85 \%$ of the vascular plants are of C3 type, and show very low values of $\delta{ }^{13} \mathrm{C}$, between -22 and $-30 \%$. The plants that generated the charcoal level here analysed are comprised into the last mentioned interval of $\delta{ }^{13} \mathrm{C}$ values. Otherwise, the values of $\mathrm{C} 4$ plants range between -10 and $-14 \%$, much higher that the amounts obtained in this work. C4 plants correspond to the $15 \%$ of land plant and mainly comprise tropical herbs. The pyrolysis quantification analysis is shown in Table 2.

Table 2 Pyrolysis quantification data of the charcoal sample 05CA2

\begin{tabular}{|c|c|c|c|c|c|c|c|c|c|}
\hline \multirow[t]{2}{*}{ Lab record } & \multirow[t]{2}{*}{ Sample } & \multirow[t]{2}{*}{ TOC } & $S 1$ & $S 2$ & $S 3$ & \multirow[t]{2}{*}{$T^{\circ} \mathrm{C}$} & \multirow[t]{2}{*}{$S 1 / \mathrm{TOC}$} & \multirow{2}{*}{$\frac{S 3 / \text { TOC }}{\mathrm{O} \text { index }}$} & \multirow{2}{*}{$\begin{array}{l}S 1 / S 1+S 2 \\
\text { Productivity index }\end{array}$} \\
\hline & & & $\mathrm{mg} / \mathrm{g}$ & & & & & & \\
\hline LC-07-005 & 05CA2 & 0.37 & 0.01 & 0 & 0.29 & $274{ }^{\circ} \mathrm{C}$ & 3 & 78 & 1 \\
\hline
\end{tabular}


These data indicate severe maturity for charcoal material. The charcoal amount and the record of kaolinite in this bed could indicate, following the paleogeographic reconstruction of Scotese et al. (1999), that the paleoclimatic conditions were warm to cool temperate.

Acknowledgements Financial support for this chapter was provided by grant Projects 647 and 199 CONICET (Argentina). The authors want to express their thanks to Dianne Edwards (Cardiff, UK) for numerous suggestions and comments in the early draft of the paper. We also thank to Marcelo Manassero, Paulina Abre and María Cecilia Amenábar for kind comments.

\section{References}

Cramer FH (1964) Some acritarchs of the San Pedro formation (Gedinniano) of the Cantabrian Mountains in Spain. Bull Soc Belge Géol 73:33-38

Cuerda AJ, Cingolani CA (1998) El Ordovícico de la región del Cerro Bola en el Bloque de San Rafael, Mendoza: sus faunas graptolíticas. Ameghiniana 35:427-448

Cuerda AJ, Cingolani C, Arrondo O, Morel E, Ganuza D (1987) Primer registro de plantas vasculares en la Formación Villavicencio, Precordillera de Mendoza, Argentina. Cuarto Congreso Latinoamericano de Paleontología. Actas I:179-183 (Santa Cruz de la Sierra Bolivia)

Di Persia (1972) Breve nota sobre la edad de la denominada Serie de la Horqueta-Zona Sierra Pintada, Departamento de San Rafael, Provincia de Mendoza. 4 Jornadas Geológicas Argentinas 3:29-41

Dorning KJ (1981) Silurian acritarchs from the type Wenlock and Ludlow of Shropshire, England. Rev Palaeobot Palynol 34:175-203

Edwards D, Morel E, Poiré DG, Cingolani CA (2001) Land plants in the Devonian Villavicencio formation, Mendoza Province, Argentina. Rev Palaeobotany Palynol 116:1-18

Edwards D, Poiré DG, Morel E, Cingolani CA (2009) Plant assemblages from SW Gondwana: further evidence for high - latitude vegetation in the Devonian of Argentina. Bassett MG (ed) Early Palaeozoic Peri-Gondwana terranes: new insights from tectonics and biogeography, vol 325. Geological Society, London (Special Publications), pp 233-255

Fensome RA, Williams GL, Barss MS, Freeman MJ, Hill JM (1990) Acritarchs and fossil prasinophytes: an index to genera, species and intraspecific taxa. American Association of Stratigraphic Palynologists, Contribution Series No 25, $771 \mathrm{pp}$

Gensel PG, Andrews HN (1984) Plant life in the Devonian. Praeger Publishers, New York, 380 pp

González Díaz EF (1972) Descripción geológica de la Hoja 27d, San Rafael, Mendoza. Servicio Minero-Geológico, Boletín, vol 132. 127 pp (Buenos Aires)

González Díaz EF (1981) Nuevos argumentos a favor del desdoblamiento de la denominada Serie de La Horqueta del Bloque de San Rafael, Provincia de Mendoza. $8^{\circ}$ Congreso Geológico Argentino. Actas 3:241-256 (Buenos Aires)

Kenrick P, Crane PR (1997) The origin and early diversification of land plants, a cladistic study. Smithsonian Institution Press, Washington, $441 \mathrm{pp}$

Lang WH, Cookson IC (1935) On a flora, including vascular land plants, associated with Monograptus, in rocks of Silurian age, from Victoria, Australia. Phil Trans R Soc London 224B:421-449

Le Hérissé A (1989) Acritarches et kystes d'algues prasinophycées du Silurien de Gotland, Suede. Palaeontographia Italica 76:57-302

Loeblich AR Jr., Drugg WS (1968) New acritarchs from the Early Devonian (late Gedinnian) Haragan Formation of Oklahoma, USA. Tulane Stud Geol 6:129-137

Manassero MJ, Cingolani CA, Abre P (2009) A Silurian-Devonian marine platform-deltaic system in the San Rafael Block, Argentine Precordillera - Cuyania terrane: lithofacies and 
provenance. In: Königshof P (ed) Devonian change: case studies in palaeogeography and palaeoecology, vol 314. The Geological Society, London (Special Publications), pp 215-240

Morel EM, Cingolani CA, Ganuza DG, Uriz NJ (2006) El registro de Lycophytas primitivas en la Formación Río Seco de los Castaños, Bloque de San Rafael, Mendoza. $9^{\circ}$ Congreso Argentino de Paleontología y Bioestratigrafía. Resúmenes: 47 (Córdoba)

Morel EM, Cingolani CA, Ganuza DG, Uriz NJ (2007) Primitive lycophytes record at the Río Seco de los Castaños Formation, San Rafael Block, Mendoza province, Argentina. Field Meeting of the IGCP 499, Devonian land-sea interaction: evolution of ecosystems and climate. pp 106-108 (San Juan)

Pazos P, Heredia A, Cingolani CA (2013) Nereites ichnofacies in the Río Seco de los Castaños Formation, Mendoza, Argentina: age, facies and trace-fossil content. II Reunión Argentina de Icnología. Abstracts (Santa Rosa)

Pazos P, Heredia A, Fernández DE, Gutiérrez C, Comerio M (2015) The ichnogenus Dictyodora from late Silurian deposits of central-western Argentina: ichnotaxonomy, ethology and ichnostratigrapical perspectives from Gondwana. Palaeogeogr Palaeoclimatol Palaeoecol 439:27-37

Poiré DG, Morel E (1996). Procesos sedimentarios vinculados a la depositación de niveles con plantas en secuencias silúrico-devónicas de la Precordillera. Argentina. Actas VI Reunión Argentina de Sedimentología, pp 205-210

Poiré DG, Cingolani C, Morel E (1998) Trazas fósiles de la Formation Horqueta (Silúrico), Bloque de San Rafael, Mendoza, Argentina. Tercera Reunión de Icnología y Primera Reunión de Icnología del Mercosur. Resúmenes: 24 (Mar del Plata)

Poiré DG, Cingolani CA, Morel E (2002) Características sedimentológicas de la Formación Río Seco de los Castaños en el perfil de Agua del Blanco: Pre-Carbonífero del Bloque de San Rafael, Mendoza. XV Congreso Geológico Argentino I:129-133 (Calafate)

Pöthe de Baldis ED (1999) Informe palinológico del Proyecto: Investigaciones en las unidades del Precámbrico y Paleozoico inferior del Bloque de San Rafael. Instituto de Geología (INGEO), Universidad Nacional de San Juan, Mendoza (5p, unpublished)

Rubinstein CV (1993) Primer registro de miosporas y acritarcos del Devónico inferior en el "Grupo Villavicencio", Precordillera de Mendoza, Argentina. Ameghiniana 30:219-220

Rubinstein CV (1997) Primer registro de palinomorfos silúricos en la Formación la Horqueta, Bloque de San Rafael, Provincia de Mendoza Argentina. Ameghiniana 34:163-167

Scotese CR, Boucot AJ, McKerrow WS (1999) Gondwanan palaeogeography and palaeoclimatology. J Afr Earth Sc 28:99-114 